\title{
Study the efficiency of survey of certain fungicides for the yellow yellow/pseudopeziza jonesii nannf/ medicago sativa
}

\begin{abstract}
In the period 2014-2016, a study was carried out on the effectiveness of some Pseudopeziza jonesii Nannf fungicides in Bulgarian Alaska Plants and Ruse and EFC Pleven in Bulgarian Alfalfa alfalfa. The purpose of this study is to determine the efficacy of some fungicides in reducing disease progression. Technique effectiveness of fungicides, degree of attack, reported: Impact $25 \mathrm{CK} / \mathrm{Flutriaphol} / 25 \mathrm{ml} / \mathrm{dka}$, Falcon 460EC/Tebuconazole, Spiroxamine, Triadimenol/-30ml/dka; Folicur 250W/ tebuconazole/-40ml/dka, Bayfidan 250EC/triadimenol $/-50 \mathrm{ml} / \mathrm{dka}$.
\end{abstract}

Keywords: alfalfa, medicago sativa, pseudopeziza jonesii nannf, tebuconazole, spiroxamine, triadimenol, flutriafol
Volume 2 Issue 3 - 2017

Iliana Ivanova,' Plamen Serafimov²

'Institute of Agriculture and Seed Science, Bulgaria Institute of Forage Crops, Bulgaria

Correspondence: Iliana Ivanova, Institute of Agriculture and Seed Science, Prof. Ivan Ivanov str. 7007 Rousse, Bulgaria, Email tri_dve@abv.bg

Received: August 07, 2017| Published: December 05, 2017

\section{Introduction}

Medicago sativa is a feed culture with unique characteristics: high yield and tolerance to water stress ../Leticia Quagliotto 2009/ Many algae pathogens (Pseudopeziza medicaginis) are known to damage the leaves and stems, leading to defoliation, loss Of yield and quality. Damon L Smith, et al. ${ }^{1}$ Chapman,/Foliar pathogens reduce the crude protein content of infected leaves by $22 \%$ compared to healthy plants. $^{2}$ and reduce the quality of the feed. Data on the use of fungicides in alfalfa cultivation are contradictory. According to some authors, the use of fungicides to protect plants from pathogens is a common practice. ${ }^{3}$ According to Gossen, Rimmer, ${ }^{4}$ Hwang et al. ${ }^{5}$ Frate (2014), intensive fungicide administration in lucerne crops has been established in recent years. In Bulgaria, such studies are limited, which requires the study of the effects of some fungicides on the restriction of the development of pathogens. Other authors believe that Fungicides are not widely used to protect alfalfa from leaf-borne diseases due to concerns about residues in animal feeds. Broscious, et al., ${ }^{6}$ Leath $\mathrm{K}^{7}$ studies on losses caused by leaf pathogens in lucerne show that fungicides can provide effective control of the disease and significantly increase hay yield ${ }^{6,7}$ and hay quality. ${ }^{8}$ Although fungicides effectively control disease and increase yield and quality, they should not be considered as the sole control method. Comparing the yield of the highest yield and the most advantageous treatment shows that the optimal use of fungicides will only prevent about $68 \%$ of the total losses due to leaf diseases, therefore the use of fungicides must Be integrated with other methods such as resistance, crop rotation, timely harvesting in order for producers to realize the maximum economic return on their investments Broscious, et al. ${ }^{7}$ One of the fungal diseases of alfalfa is yellow leaf spots. They are known in alfalfa in Europe, America and others Penchukova VS, et al. ${ }^{9}$ Under favorable conditions all leaves are smeared and the crop looks yellow, the leaf mass falls, and the yields decrease. Alfalfa burdens lead to changes in the chemical composition and significantly reduce the nutritional value of the feed. Infested plants are difficult to overwinter. The mushroom is retained in the attacked leaves. Losses greatly increase in years of wet and warm spring, especially in seed crops. ${ }^{10}$ This study aims to establish the efficacy of some fungicides to reduce the development of yellow leaf spot disease.

\section{Material and methods}

The researches were carried out in the AMS "Obraztsov Chiflik" Rousse and EFC Pleven. Three Bulgarian alfalfa cultivars were used. The experience is based on a block method in four iterations in the experimental field of the RASC "Obraztsov chiflik". The size of the experimental parcels is $10 \mathrm{~m}$. The fungicide test is according to the Rümmeer scheme. The investigated chemical preparations and plant treatment doses are listed in (Table 1). Two treatments with fungicides have been carried out. In phase button and beginning of blossoming of alfalfa. The first count is 14 days after the beginning of the flowering period. The second 14 days after the first treatment for the biological efficacy of the fungicide. Infected plants are used as a source of infection. The degree of attack was reported by the McK's formula by the frequency and intensity of the attack. Treating crops during vegetation when attacking over $10 \%$ of the leaf area. Testing of fungicides is carried out in Polish experience of an artificial infection background. Effectiveness of fungicides is determined by the method of Stepanov et al. ${ }^{11}$

Table I Variants of the experience

\begin{tabular}{|c|c|c|c|c|}
\hline № & Trade name & Active substance & $\begin{array}{l}\text { Dose } \\
\text { ml/Dka }\end{array}$ & Application \\
\hline I & - & Control untreated & - & - \\
\hline 2 & Impact & Flutriafol 250g/l & 25 & Vegetative \\
\hline 3 & Follicur $250 \mathrm{~EB}$ & Tebuconazole 250g/l & 40 & Vegetative \\
\hline 4 & Byfidan & Triadimenol 250g/l & 50 & Vegetative \\
\hline 5 & Falcon & $\begin{array}{l}\text { Tebuconazole } 167 \mathrm{~g} / \mathrm{l} \text {, } \\
\text { Spiroxamine } 250 \mathrm{~g} / \mathrm{l} \\
\text { Triadimenol } 43 \mathrm{~g} / \mathrm{l}\end{array}$ & 30 & Vegetative \\
\hline
\end{tabular}

\section{Results and discussion}

The disease manifests on all the aerial parts of the plants. Leaves and stems form oblong, yellow to orange or dark brown brown spots (Figure 1). The applied fungicides, with different active substances (tebuconazole, spiroxamine, triadimenol, prothioconazole), reduce the 
attack on leaf and plant stems compared to untreated variants. In the variants with the active substances tested, no significant differences were found with respect to the activity of the tested products (Table 1). There are no significant differences between the products during the treatment period. Similarly, the results obtained are obtained by monitoring the vitality and coverage of the plants. The dynamics of grass cover formation depends on the ontogenetic development of the crop and does not depend on the factors studied. The attack is close to the observed varieties. Higher effectiveness was found in the follicular preparation. The analysis of the experimental results shows that the Pseudopeziza jonesii Nannf infestation index ranges from 15.70 to $27.90 \%$ over the period of the survey (Table 2$).{ }^{12-15}$

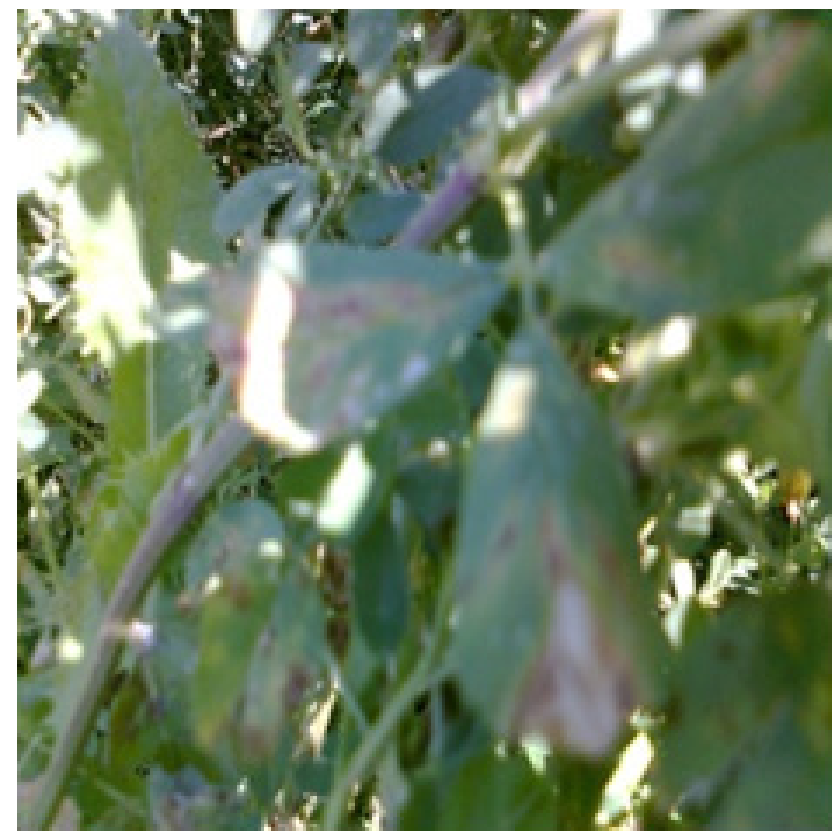

Figure I Infested by yellow spots (Pseudopeziza jonesii Nannf.) Leaves.

Table 2 Variants of the experience

\begin{tabular}{|c|c|c|c|c|c|c|c|}
\hline \multirow{3}{*}{ № } & \multirow{3}{*}{ Trade name } & \multicolumn{6}{|c|}{ Index off Atack \% } \\
\hline & & \multicolumn{6}{|c|}{ Efficacy } \\
\hline & & \multicolumn{2}{|c|}{ Prista 3} & \multicolumn{2}{|c|}{ Prista 4} & \multicolumn{2}{|c|}{ Pleven 6} \\
\hline I & $\begin{array}{l}\text { Control } \\
\text { untreated }\end{array}$ & 27,04 & 15,00 & 30,00 & 15,00 & 30,00 & 15,00 \\
\hline 2 & Impact & 19,70 & 35,00 & 26,58 & 15,00 & 27,30 & 15,00 \\
\hline 3 & Follicur 250 EB & 15,70 & 35,00 & 19,70 & 35,00 & 19,00 & 35,00 \\
\hline 4 & Byfidan & 21,35 & 20,00 & 25,30 & 15,00 & 27,90 & 15,00 \\
\hline 5 & Falcon & 22,10 & 20,00 & 25,00 & 15,00 & 26,00 & 15,00 \\
\hline
\end{tabular}

\section{Conclusion}

The test substances applied vegetatively in lucerne do not induce phytotoxicity of the culture and limit the development of the pathogen. Although fungicides control disease and increase yield and quality, they should not be considered as the only control method.

\section{Acknowledgements}

None.

\section{Conflict of interest}

The author declares no conflict of interest.

\section{References}

1. Damon L Smith, Scott Chapman, Bryan Jensen, et al. Using fungicides on alfalfa for dairy production in wisconsin. Cooperative Extension Publishing; 2015. 4 p.

2. Sheau-Fang Hwang, Heping Wang, Bruce D Gossen, et al. Impact of foliar diseases on photosynthesis, protein content and seed yield of alfalfa and efficacy of fungicide application. European Journal of Plant Pathology. 2006;115(4):389-399.

3. Shu-Kang Chen, Clive A Edwards, Scott Subler. Effects of the fungicides benomyl, captan and chlorothalonil on soil microbial activity and nitrogen dynamics in laboratory incubations. Soil Biology and Biochemistry. 2001;33(14):1971-1980.

4. Gossen B, Rimmer S. First report of resistance to benomyl fungicide in sclerotinia sclerotiorum. Plant disease. 2001;85(11):1206.

5. Hwang, Sheau-Fang, Wang H, et al. Preliminary research results on the use of foliar fungicides in alfalfa production. Animal Industry Reports. 2006;659(2013).

6. Broscious SC. Economic evaluation of fungicides for control of alfalfa foliar diseases. Diseases Control and Pest Management. 1988. 934-939 p.

7. Leath K. Pest management systems for alfalfa diseases. Pimentel 2 nd ed. 293-302 CRC handbook of pest management in agriculture. Vol I, USA: CRC press; 1981. p. 1-656.

8. Morgan WC, Parbery DG. Depressed fodder quality and increased oestrogenic activity of lycerne infected with Ps. Medicaginis Aust J Agric Res. 1980;31:1103-1110.

9. Penchukova VC, Myermanov G. Specialties of the immunological evaluation of alfalfa. Proteinata rastniy magazine. 1986;12:23-25.

10. Graham JH, Stuteville D, Frosheiser F, et al. A compendium of alfalfa diseases. American Phytopathological Society. 1979. p. 1-65.

11. Stepanov K, Chumakov A. Forecast of painful agricultural crops. Leningrad: Kolos; 1972.

12. Leticia Quagliotto, Gastón Azziz, Natalia Bajsa, et al. Three native Pseudomonas fluorescens strains tested under growth chamber and field conditions as biocontrol agents against damping-off in alfalfa. Biological Control. 2009; $15(1): 42-50$

13. Moussart A, Onfroy C, LesneA, et al. Host status and reaction of Medicago truncatula accessions to infection by three major pathogens of pea (Pisum sativum) and alfalfa (Medicago sativa). European Journal of Plant Pathology. 2007;117(1):57-69.

14. Willis WG, Stuteville DL. Effect of leaf and stem diseases on yield and quality of alfalfa forage. Crop Sci. 1969;9(5):637-640.

15. Sooväli P, Kangor T, Tamm I. The incidence of fungal diseases in oat leaves and yields as affected by fertilizer and chemical inputs in Estonia. Agronomy Research. 2010;8(Special Issue II):475-480. 